\title{
Synthetic Efforts for Stereo Structure Determination of Cytotoxic Marine Natural Product Pericosines as Metabolites of Periconia sp. from Sea Hare
}

\author{
Yoshihide Usami,* Hayato Ichikawa and Masao Arimoto
}

Osaka University of Pharmaceutical Sciences, 4-20-1 Nasahara, Takatsuki, Osaka 569-1094, Japan

* Author to whom correspondence should be addressed; E-mail: usami@gly.oups.ac.jp

Received: 10 January 2008; in revised form: 18 March 2008 / Accepted: 19 March 2008 /

Published: 24 March 2008

\begin{abstract}
Pericosines are unique $\mathrm{C}_{7}$ cyclohexenoid metabolites of Periconia byssoides OUPS-N133 fungus that was originally isolated from the sea hare, Aplysia kurodai. Pericosines show significant in vitro cytotoxicity against P388 lymphocytic leukemia cells. Pericosine A, in particular, shows the most potent activity and significant in vivo antitumor activity against P388 cells. Thus, pericosines are promising candidates for seed compounds of anticancer drugs. However, before the total syntheses of pericosines were accomplished, their stereo structures could not be determined by spectral analyses because they have multifunctionalized cyclohexenoid structures with torsional strain. In this review, synthetic efforts for pericosines in this decade are surveyed.
\end{abstract}

Keywords: marine natural product, antitumor, pericosine, structure determination, total synthesis, carbasugar

\section{Introduction}

Synthetic studies of carbasugars have been progressing on a worldwide scale [1-3]. Carbasugars are a class of carbocyclic analogues of monosaccharides in which oxygen atom in the ring is replaced with a carbon atom. Because of this, they are also called pseudo-sugars. Carbasugars exhibit gycosidase inhibitory, antitumor (including anticancer), antiviral, antifungal, antibacterial, and antimalarial activities. Therefore, the synthetic study of carbasugars is extremely important for the discovery of 
new drugs, including cancer preventive drugs. Mammals lack the shikimate pathway found in plants, fungi, microorganisms, and apicomplexan parasites. The chances of drug discovery are improved when shikimate analogues are focused on.

Figure 1 illustrates the structures of representative carbasugars as synthetic targets, including 2-crotonyloxy-(4R,5R,6R)-4,5,6-trihydroxy-cyclohex-2-enone $\quad(\mathrm{COCT}) \quad[4-15], \quad[(-)-\mathrm{KD} 16-\mathrm{U} 1$ [gabosine A [16-21], (+)-MK7607 [22,23], (+)-valienamine [24-29], (+)-validamine [29-31], Relenza ${ }^{\circledR}$ [32], and Tamiflu ${ }^{\circledR}$ [33-40], COCT [41], (-)-KD16-U1 [42], and gabosines [43], which were isolated from cultures of Streptomyces spp., are potential glyoxalase inhibitors and therefore show promise as anticancer agents. (+)-MK7607, which was isolated from cultures of Curvularia eragrostidis D2452, showed herbicidal activity [44]. (+)-Valienamine and (+)-validamine were obtained from the degradation of antifungal antibiotic validamycin A by Pseudomonas denitrificans [45-47]. Valienamine is also a component of ascarbose, a potent $\alpha$-glucosidase inhibitor [48].

Relenza and Tamiflu are the most popular anti-influenza drugs today and are therefore attractive target molecules for synthetic studies. Relenza is a potent anti-influenza drug designed from the transition structure of $\mathrm{N}$-acetylneuramic acid-neuramidase complex based on X-ray analysis [32]. The oral anti-influenza drug Tamiflu has received immense attention for its effect on avian flu. To this day, however, the synthesis of Tamiflu remains an enigma for synthetic organic chemists. The independent asymmetric total synthesis of Tamiflu by Corey [35] and Shibasaki [36,37] from non-natural starting material, which was published in JACS, was a hot topic in 2006. In 2007, Fukuyama and co-workers reported the practical synthesis of Tamiflu [38].<smiles>[R]OCC1=C[C@H](O)[C@@H](O)[C@H](O)C1=O</smiles>

COCT: $\mathrm{R}=-\mathrm{COCH}=\mathrm{CHCH}_{3}$ $(-)-K D 16-U 1: R=H$<smiles>CC1=C[C@@H](O)[C@H](O)[C@H](O)C1=O</smiles>

gabosine A<smiles>OCC1=C[C@H](O)[C@H](O)[C@H](O)C1O</smiles>

(+)-MK7607<smiles>N[C@H]1C=C(CO)[C@@H](O)[C@H](O)[C@H]1O</smiles>

$(+)$-valienamine<smiles>N[C@H]1CC(CO)[C@@H](O)[C@H](O)[C@H]1O</smiles>

$(+)$-validamine

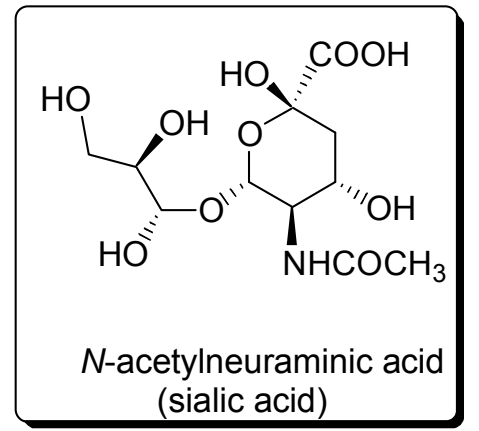<smiles>OCC(O)C(O)C(O)CO</smiles><smiles>[Y2]C=NC(=N)N[C@H]1C=C(C(=O)O)O[C@@H](O)[C@@H]1NC(C)=O</smiles>

zanamivir hydrate $\left(\right.$ Relenza $^{\mathrm{TM}}$ )<smiles></smiles>

oseltamivir phosphate

(Tamiflu ${ }^{\mathrm{TM}}$ )

Figure 1. Structures of bioactive carbasugars as synthetic targets. 
In the past several decades, scientists working on new drug discovery have extended their research field to include the ocean because of its vast biological/chemical diversity and the fact that it composes almost $70 \%$ of Earth's surface. Marine natural products chemistry has produced a number of promising candidates for anticancer drugs and several of them have undergone pre- or phases I-III clinical trials [49,50]. Recently, however, a new tide has emerged, which involves the study of metabolites of microorganisms from marine sources [51-53]. It must be emphasized that researchers involved in this endeavor have been attempting preservation of environmental habitat in the ocean. In 1997, Numata and co-workers isolated unique $\mathrm{C}_{7}$ cyclohexenoid-type metabolites from Periconia byssoides OUPS-N133 fungus that was originally isolated from the sea hare, Aplysia kurodai, and designated them as pericosines A 1 and B 2 (Figure 2), together with some macrospherides [54]. Full details of the isolation of pericosines A-E 1-5 were very recently reported by Numata and co-workers [55]. Pericosines showed significant in vitro cytotoxicity against P388 lymphocytic leukemia cells. Particularly, 1 was reported to have inhibitory activity against protein kinase and topoisomerase II in addition to significant in vivo antitumor activity against P388 cells. Thus, pericosines are thought to be promising candidates for seed compounds of anticancer drugs. However, total syntheses were required to confirm the stereo structures of most pericosines because the multifunctionalized cyclohexenoid structures with severe torsional strain have made structure determination by spectral analyses difficult. In this review, synthetic efforts to produce pericosines and analogues $\mathbf{1}$, 2, 4-7, and 9 from (-)-shikimic acid 10 or (-)-quinic acid 11 are surveyed comprehensively, together with the discovery of natural compounds.<smiles>COC(=O)C1=C[C@@H](O)C(O)(O)[C@@H](O)C1Cl</smiles>

$(+)$-pericosine A 1<smiles>COC(=O)C1=C[C@@H](O)[C@H](O)[C@H](O)[C@H]1C</smiles>

(+)-pericosine B 2<smiles>COC(=O)C1=C[C@@H](O)[C@H](O)[C@H](O)[C@H]1OC</smiles>

(-)-pericosine C 3

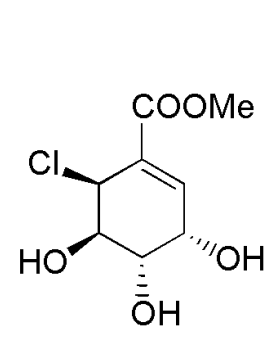

pericosine D 4

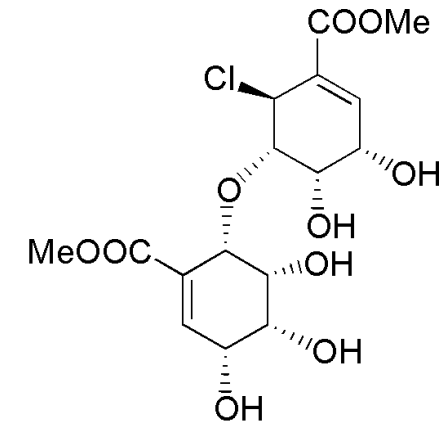

pericosine $\mathbf{E} \mathbf{5}$<smiles>CC(=O)C1=C[C@H](O)[C@H](O)[C@H](O)[C@H]1Cl</smiles>

initially assigned pericosine $A$

6<smiles>COC(=O)C1=C[C@@H](O)[C@H](O)[C@@H](O)[C@H]1OC</smiles>

epimer of pericosine $B$ $((+)$-pericosine $\mathrm{C})$ 7<smiles>CO[C@H]1C(C(C)=O)=C[C@@H](O)[C@H](O)[C@H]1O</smiles>

initially assigned pericosine $\mathrm{C}$ 8<smiles>CC(=O)C1=C[C@@H](O)[C@H](O)[C@H](O)[C@H]1Cl</smiles>

initially assigned pericosine $\mathrm{D}$ 9

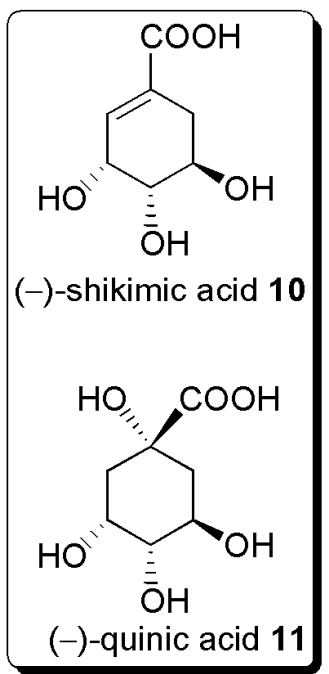

Figure 2. Structures of pericosines and analogues. 


\section{Isolation of Pericosines from Periconia byssoides [54,55]}

Numata and co-workers reported the isolation of $\mathrm{C}_{7}$ cyclohexenoids designated as pericosines A-E 1-5 in 1997 and 2007, as summarized below. The fungal strain P. byssoides OUPS-N133 was isolated from a culture of $A$. kurodai by bioactivity-guided cytotoxicity assay using P388 cells. The fungal strain was cultured in artificial seawater medium containing $1 \%$ malt extract, $1 \%$ glucose, and $0.05 \%$ peptone adjusted to $\mathrm{pH} 7.5$ at $27{ }^{\circ} \mathrm{C}$. After 4 weeks, mycelia obtained by filtration of the broth were extracted with AcOEt. The AcOEt extract was separated by gel filtration through Sephadex LH-20 using $\mathrm{MeOH}-\mathrm{CH}_{2} \mathrm{Cl}_{2}$ (1:1), followed by silica gel column chromatography with $\mathrm{CH}_{2} \mathrm{Cl}_{2}-\mathrm{MeOH}$ gradient solvent system. This separation was performed along with in vitro P388 cytotoxicity assay. The active fraction that was eluted with $10 \% \mathrm{MeOH}-\mathrm{CH}_{2} \mathrm{Cl}_{2}$ was further purified by reverse phase preparative HPLC using the $\mathrm{MeOH}-\mathrm{H}_{2} \mathrm{O}$ solvent system to afford 1-5. Spectroscopic analyses including NMR, MS, and IR led to the elucidation of their structures. Early studies, however, indicated the structure of pericosine $A$ as $\mathbf{6}$, that of pericosine $C$ as $\mathbf{8}$, and that of pericosine $D$ as $\mathbf{9}$ [56,57]. It is difficult to determine the relative configuration of such compounds as pericosines because they possess a multi-functionalized cyclohexenoid core with torsional strain. In their most recent report, the authors stated that they elucidated the structures of pericosines, except for pericosine A, by spectroscopic analyses. They determined the relative chemistry of pericosine B 2 on the basis of NOE between H-3 and H-5 observed in its acetonide 2a and small coupling constants $J_{3-4}=5.7 \mathrm{~Hz}$, $J_{4-5}=3.1 \mathrm{~Hz}$, and $J_{5-6}=4.1 \mathrm{~Hz}$. Long-range coupling between $\mathrm{H}-4 / \mathrm{H}-6, \mathrm{H}-2 / \mathrm{H}-6$, and H6/H-2 observed in 2a also supported their proposed configuration. Similar NOE between H-3 and H-5 and long-range coupling between $\mathrm{H}-2 / \mathrm{H}-6$ and $\mathrm{H}-4 / \mathrm{H}-6$ were observed in the spectra of 2, suggesting similar configuration. Pericosine C 3, which has the same planar structure as pericosine B 2, was transformed into acetonides $\mathbf{3 a}$ and $\mathbf{3 b}$. Spectral analysis indicated that the 3,4,5-trihydroxyl groups on the cyclohexene ring had cis, cis configuration, and the stereochemistry at C-6 was determined to be different from that of $\mathbf{2}$. Finally, its identity was confirmed by comparing with synthesized compound 7. Interestingly, pericosine $\mathrm{C}$ exists as an enantiomeric mixture of $\mathbf{3}$ and $\mathbf{7}$, based on comparison of specific rotation values between natural pericosine $C\left([\alpha]_{D}{ }^{25}-4.8\right)$ and synthetic $7\left([\alpha]_{\mathrm{D}}{ }^{25}+35.1\right)$. The relative chemistry of pericosine D 4 was determined on the basis of NOE between one acetonide-methyl/H-3, H-4 and another acetonide-methyl/H-5 observed in the NOESY spectrum of its 3,4-acetonide. The relative chemistry of pericosine E 5 was confirmed by X-ray analysis. Pericosine $\mathbf{E}$ also exists as an enantiomeric mixture.

Table 1. Cytotoxicity of pericosines against murine P388 cell line.

\begin{tabular}{rccc}
\hline Pericosine A & Pericosine B & Pericosine C & Pericosine D Pericosine E \\
\hline $\mathrm{ED}_{50}(\mu \mathrm{g} / \mathrm{mL}) 0.1$ & 4.0 & 10.5 & 3.015 .5 \\
\hline
\end{tabular}

Pericosines are responsible for the cytotoxicity of the extract of $P$. byssoides. The $\mathrm{ED}_{50}$ values of pericosines are presented in Table 1. Compounds 1, 2, and $\mathbf{4}$ exhibited significant in vitro cytotoxicity against P388 cells. Most potent $\mathbf{1}$ also showed in vivo antitumor activity against P388 cells. Furthermore, 1 inhibited protein kinase EGFR and human topoisomerase II and showed selective 
growth inhibition against human cancer cell lines HBC-5 and SNB-75. Thus, pericosines were proved to be promising candidates for seed compounds of cancer preventive drugs.

\section{Synthetic Efforts for Pericosines}

As described above, the syntheses of pericosines are required not only to determine absolute configuration but also to confirm relative stereochemistry. The following are synthetic efforts by several groups carried out so far.

\subsection{Total synthesis of pericosine B [58]}

\subsubsection{Donohoe's approach}

Donohoe and co-workers were the first to report the total synthesis of pericosine B (+)-2 in 1998. This is the only successful synthesis to date and has been achieved by using their original hydrogen-bond-directed dihydroxylation with osmium tetroxide to give cis,cis-triol. The synthesis is summarized in Scheme 1.<smiles>O[C@H]1C=CC=C(Br)[C@@H]1O</smiles>

12

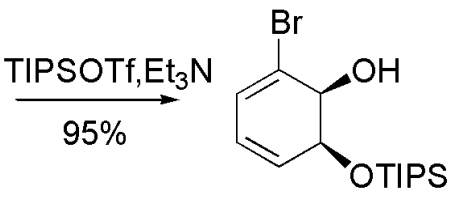

13
1) $\mathrm{NaH}, \mathrm{Mel},-15^{\circ} \mathrm{C}$

2) $\overrightarrow{\text { TBAF, } 61 \%}$<smiles>CO[C@H]1C(Br)=CC=C[C@H]1O</smiles>

14<smiles>CO[C@@H]1C(Br)=C[C@H](O)[C@H](O)[C@@H]1O</smiles>

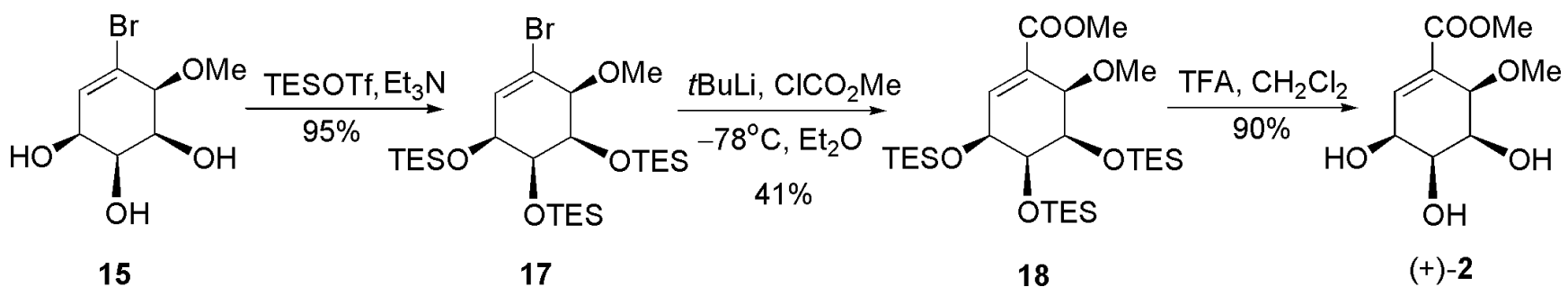

Scheme 1. Successful total synthesis of $(+)$-pericosine B by Donohoe and co-workers.

Commercially available (+)-dihydroxybromocyclohexadiene $\mathbf{1 2}$ was selectively protected to give silyl ether 13, which was then $O$-methylated with $\mathrm{NaH}$ and $\mathrm{MeI}$ and deprotected with TBAF to give alcohol 14. The subsequent hydrogen-bond-directed dihydroxylation of 14, which was the key step of this total synthesis, was carried out with stoichiometric osmium tetroxide and one equivalent of quinuclidine to give syn,syn- and syn,anti-triols, 15 and 16, in 2.2: 1 ratio. Separated 15 was protected with triethylsilyl (TES) groups to give 17, and $\mathbf{1 7}$ was methoxycarbonylated to yield $\mathbf{1 8}$. The synthesis 
was terminated by the addition of TFA to afford 2, which had the same spectroscopic data including specific rotation as those of the natural product, leading to the conclusion that the absolute stereochemistry is methyl (3S,4S,5S,6R)-3,4,5-trihydroxy-6-methoxycyclohexene-1-carboxylate. The problems of this synthesis included poor stereoselectivity in the crucial step and use of a stoichiometric amount of highly toxic osmium tetroxide.

\subsubsection{Okamura's approach [59]}

Okamura and co-workers attempted the total synthesis of pericosine B also in 1998. The key reaction of their synthesis was the asymmetric Diels-Alder reaction of 3-hydroxy-2-pyrone 19 with a basic catalyst. Their synthetic approach is illustrated in Scheme 2.

The enantioselective Diels-Alder reaction between 3-hydroxy-2-pyrone 19 and acrylate with chiral auxiliary $\mathbf{2 0}$ was carried out in the presence of cinchonidine as basic catalyst to give endo-adduct $\mathbf{2 1}$ in 93\% yield with $95 \%$ de. Adduct 21 was then treated with $\mathrm{NaOMe}$ to remove chiral auxiliary and the resultant methyl ester was dihydroxylated with catalytic osmium tetorxide and NMO to afford exo-diol, which was protected as benzylidene acetal 22. Reduction with $\mathrm{LiAlH}_{4}$ followed by treatment with $\mathrm{NaIO}_{4}$ gave diol 23, which was successively protected with a primary hydroxyl group such as TBS-ether followed by a secondary hydroxyl group such as pivaloyl ether to give ketone 24 . Stereoselective reduction with $\mathrm{NaBH}_{4}$ afforded $\beta$-hydroxyalcohol, which was then $O$-methylated and deprotected with TBAF to give hydroxymethylether 25. Unfortunately, the completion of this synthesis from the intermediate has not been reported so far.

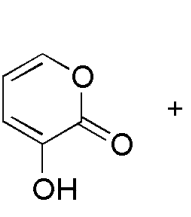

19<smiles>C=CC(=O)N1C(=O)OCC1[PH2+]</smiles>

20

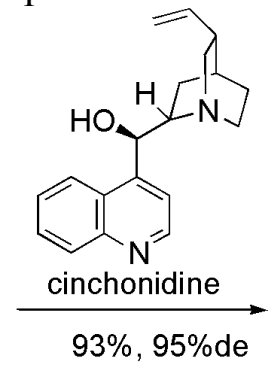

22 $\underset{8 \% \text { in } 2 \text { steps }}{\stackrel{\text { 2) } \mathrm{NaIO}_{4}}{\longrightarrow}}$

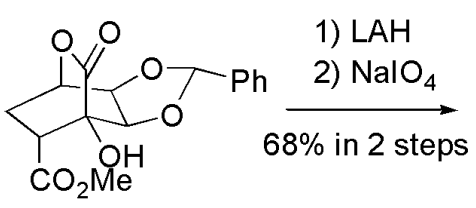

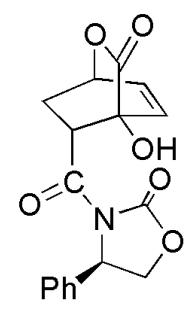

21

1) $\mathrm{NaOMe}, \mathrm{MeOH},-78^{\circ} \mathrm{C}$

2) $\mathrm{OsO}_{4}, \mathrm{NMO}$

3) $\mathrm{PhCHO}$, PPTS

$76 \%$ in 3 steps<smiles>O=C1[C@H](CO)C[C@@H](O)[C@H]2OC(c3ccccc3)O[C@H]12</smiles>

23<smiles>CC(C)COC[C@H]1C[C@@H](O[Na])C2OC(c3ccccc3)O[C@@H]2C1=O</smiles>

24

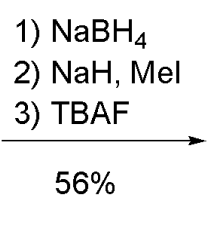

2) $\mathrm{NaH}$

3) TBAF

$56 \%$<smiles>CO[C@H]1C[C@@H](CO)[C@@H](O[Na])O[C@H]1OCc1ccccc1</smiles>

25
1) TBSOTf

2) $\mathrm{PivCl}, \mathrm{Et}_{3} \mathrm{~N}$

$50 \%$

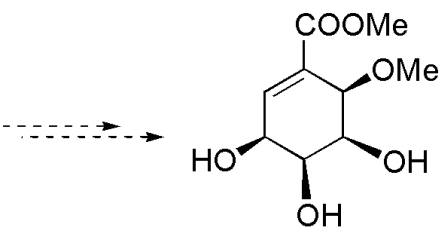

(+)-2

Scheme 2. Okamura's approach. 


\subsubsection{Usami's approach [60]}

An approach taken by our group toward pericosine B is shown in Scheme 3. Racemic Diels-Alder adduct 27, which was formed by reacting methyl acrylate 26 with furan in the presence of $\mathrm{ZnCl}_{2}$ as Lewis acid catalyst, was dihydroxylated with $\mathrm{H}_{2} \mathrm{O}_{2}$ and catalytic osmium tetroxide with excellent exo-face selectivity. Acetonides $\mathbf{2 8}$ derived from the mixture of diastereoisomers $\mathbf{2 7}$ were treated with LHMDS in THF at $-78^{\circ} \mathrm{C}$ to give methyl 5-epishikimate derivative 29 as a single product, whose hydroxyl group at C-5 was protected as silyl ether 30. Compound 30 was dihydroxylated with osumium tetroxide to give sole product 31 with the desired stereochemistry. After many examinations of regioselective $O$-methylation and $O$-acylation of 31 , it was protected at C-2 by acetylation to give 32, then deprotected with 5-TBS ether to give alcohol 33, which in turn was oxidized with Dess-Martin periodinane to give $\beta$-hydroxyketone 34. $\alpha, \beta$-Unsaturated ketone 35 obtained by adding TFAA to 34 was reduced with $\mathrm{NaBH}_{4}$ to give alcohol 36 with the desired stereochemistry of $\mathbf{3 7}$, followed by protection and deprotection. Alcohol 38 was oxidized with Dess-Martin periodinane to give unstable $\alpha, \beta$-unsaturated enone 39, which could not be purified by silica gel chromatography. Crude 39 was reduced to generate hydroxyl group with the desired stereochemistry. However, not our objective reaction but an unexpected reaction occurred to yield 40. This work was published in 2004.
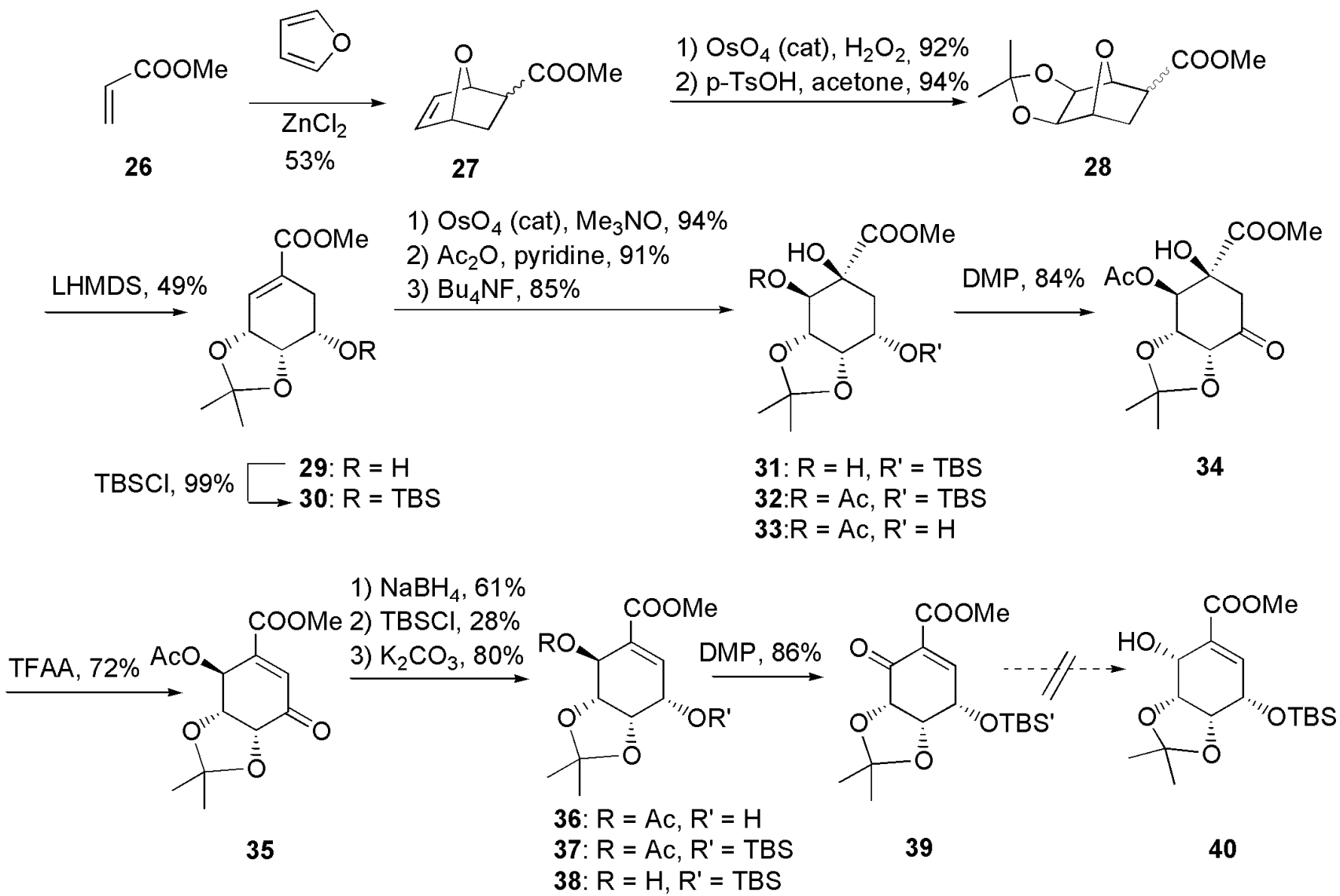

Scheme 3. Usami's approach. 


\subsubsection{Garcia Ruano’s approach [61]}

Garcia Ruano and co-workers reported their attempt to synthesize pericosine B in 2005. As shown in Scheme 4, asymmetric Diels-Alder cycloaddition reaction between chiral 3-sulfinylacrylonitrile 41 and furan with $\mathrm{Me}_{2} \mathrm{AlCl}$ as Lewis acid catalyst gave endo adduct 42 in 53\% yield together with exo adduct in 10\% yield [62]. The double bond in $\mathbf{4 2}$ was dihydroxylated exo-face selectively. The newly generated two hydroxyl groups were protected as acetonide 43, and this was converted into $\alpha, \beta$-unsaturated nitrile 44 by basic treatment with $\mathrm{NaNH}_{2}$. Treatment with $\mathrm{MeOH}$, followed by triethylamine and TMSOTf, afforded ring-opened nitrile $\mathbf{4 5}$, which seemed to be the last intermediate in the synthesis of $\mathbf{2}$. However, the subsequent transformation of cyano group into methoxycarbonyl group by methanolysis has not been reported so far.

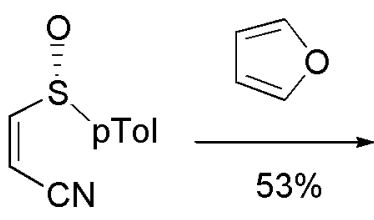

41

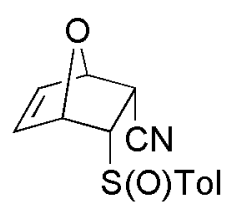

42

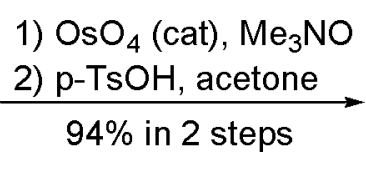

$\underset{94 \% \text { in } 2 \text { steps }}{\stackrel{\text { p-TsOH, acetone }}{\longrightarrow}}$

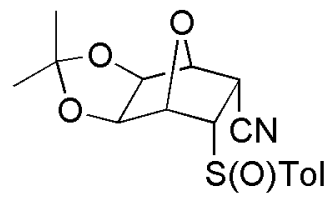

43

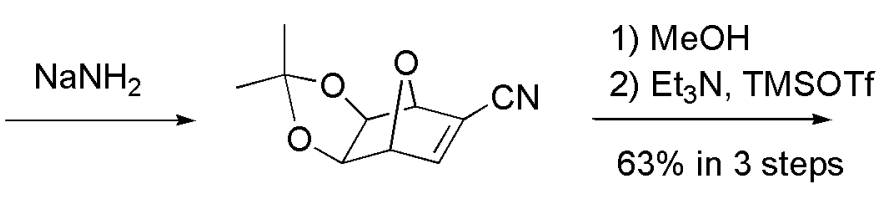

44

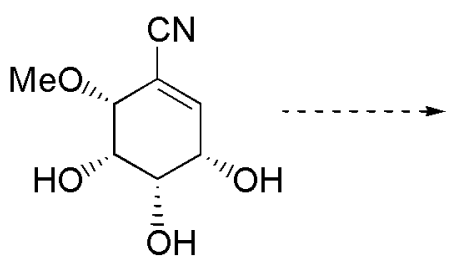

45<smiles>CO[C@H]1C(C(C)=O)=C[C@@H](O)[C@H](O)[C@H]1O</smiles>

2

Scheme 4. Garcia Ruano’s approach involving asymmetric Diels-Alder cycloaddition.

\subsection{Total synthesis of epimer of pericosine B: Synthesis of pericosine C [63]}

As described above, our synthesis of pericosine B could not be completed. Thus, we attempted to synthesize the epimer of pericosine B 7, as summarized in Scheme 5. Known methyl shikimate derivative 46 from (-)-quinic acid 11 was converted into TBS ether 47, which was reacted with catalytic osmium tetroxide and one equivalent of trimethylamine- $N$-oxide under reflux with $t$ BuOH-pyridine- $\mathrm{H}_{2} \mathrm{O}(20: 5: 1)$ to give a mixture of diols 48 and 49 in $3: 1$ ratio in $40 \%$ yield with recovery of 47 (33\%). Major diol 48 was selectively $O$-methylated at C-6 to give $\mathbf{5 0}$ in $66 \%$ yield as a single product, whereas minor diol 49 was singly 6-O-methylated to give 51 in $16 \%$ yield with $20 \%$ of 1,6-bis- $O$-methylated product. 6- $O$-Methyl ether 51 was further examined for its potential use in the synthesis of pericosine B 2, but all attempts were unsuccessful. Deprotection of methyl ether $\mathbf{5 0}$ with TBAF produced alcohol 51, and oxidation of $\mathbf{5 1}$ with Dess-Martin periodinane gave ketone 52, which in turn was dehydrated with TFAA to yield unsaturated ketone 53. Enone 53 was reduced with $\mathrm{NaBH}_{4}$ in excellent stereoselectivity to give alcohol 54, and this was then converted into target molecule (+)-7. When tested for in vitro for cytotoxicity against P388 cells, obtained $(+)-7$ gave an $\mathrm{ED}_{50}$ value of $17.8 \mu \mathrm{g} / \mathrm{mL}$, which indicated lower activity than natural pericosine $\mathrm{B}\left(\mathrm{ED}_{50}: 4 \mu \mathrm{g} / \mathrm{mL}\right)$. 
Thus, we concluded that the stereochemistry of C-6 had a significant influence on cytotoxicity. When this work was published in 2004, synthesized (+)-7 was a non-natural product. However, it was elucidated later that $(+)-7$ had the same relative chemistry as natural pericosine A $\mathbf{1}$ and was a component of natural pericosine $\mathrm{C}$, which is an enantiomeric mixture of $\mathbf{3}$ and 7 [55].<smiles>O=C(O)C1(O)C[C@@H](O)C(O)[C@H](O)C1</smiles>

$(-)$-quinic acid 11

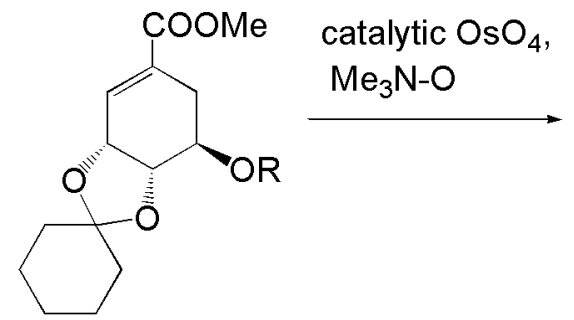

46: $\mathrm{R}=\mathrm{H}$

47: $R=$ TBS
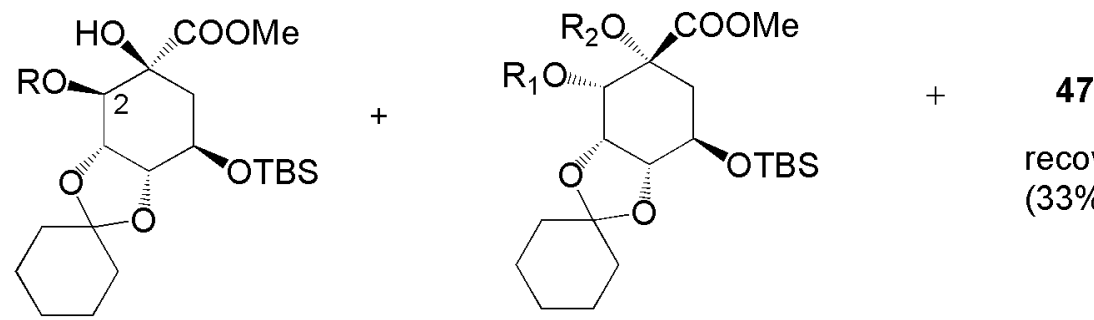

recovery

$(33 \%)$

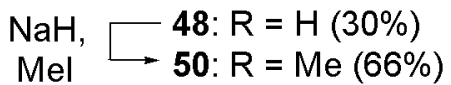

$49: \mathrm{R}_{1}=\mathrm{R}_{2}=\mathrm{H}(10 \%) \longrightarrow \mathrm{NaH}$,

51: $R_{1}=M e, R_{2}=H(20 \%)^{\star} \mathrm{Mel}$

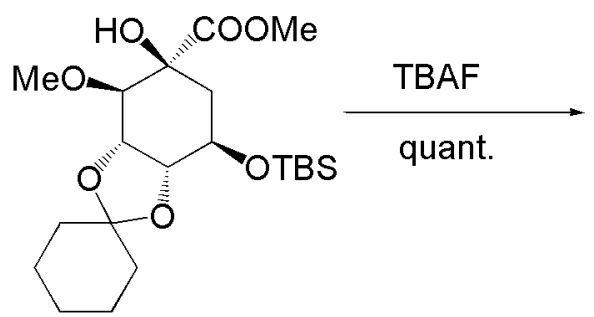

50<smiles>COC(=O)[C@]1(O)C[C@@H](O)[C@H]2OC3(CCCCC3)O[C@H]2[C@H]1OC</smiles>

51

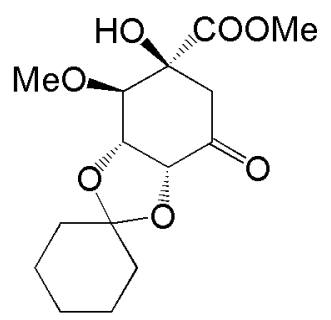

52

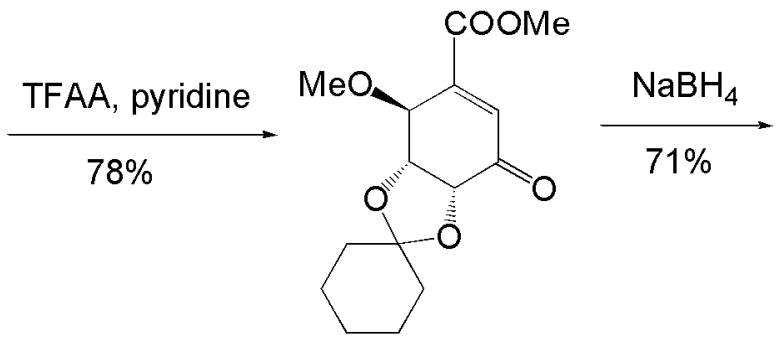

53<smiles>COC(=O)C1=C[C@@H](O)[C@H]2OC3(CCCCC3)O[C@H]2[C@H]1OC</smiles>

TFA, MeOH<smiles>COC(=O)C1=C[C@@H](O)[C@H](O)[C@H](O)[C@H]1OC</smiles>

54

$(+)-7$

Scheme 5. Synthesis of epimer of pericosine B from (-)-quinic acid. 


\subsection{Total synthesis of initially assigned pericosines A and D [64,65]}

After the publication of the total synthesis of pericosine B 2 by Donohoe, there had been no reports of pericosine $\mathrm{A}$ in spite of its antitumor activity. Then, the total synthesis of initially assigned pericosines A 6 and D 9 was attempted by our group because those two target compounds seemed to be synthesized via common intermediate enone $\mathbf{5 5}$ derived from (-)-quinic acid 11. Our retro-synthetic strategy is shown in Scheme 6. Key reactions of this synthesis included $\alpha$-face selective chlorination of silylenolether derived from known ketone 59 [66,67] and reagent-dependent stereoselective reduction of $\mathbf{5 5}$.<smiles>COC(=O)C1=C[C@@H](O)[C@H](O)[C@H](O)[C@H]1Cl</smiles>

6<smiles>COC(=O)C1=C[C@@H](O)[C@H](O)[C@H](O)[C@H]1Cl</smiles>

9

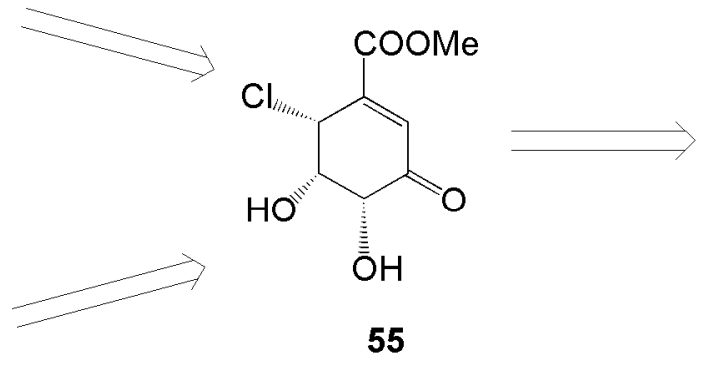<smiles>CC(=O)C1(O)CC(=O)[C@@H]2OC(C)(C)O[C@H]2[C@H]1Cl</smiles>

56<smiles>C1=CCCC1</smiles><smiles>CCCO[C@H]1C2CC(O)(C(=O)O2)C(O)[C@@H]1Cl</smiles>

57<smiles>CCCCO[C@@H]1C(=O)[C@H](Cl)[C@]2(O)C[C@H]1OC2=O</smiles>

58<smiles>CCCCO[C@@H]1C(=O)C[C@]2(O)C[C@H]1OC2=O</smiles>

59<smiles>C#CC=CC1C[C@@](O)(C(=O)O)C[C@H](O)[C@@H]1O</smiles>

$(-)$-quinic acid 11

Scheme 6. Retro-synthetic strategy of 6 and 9.

The synthesis of $\mathbf{6}$ was carried out as illustrated in Scheme 7. Lactone 59 derived from (-)-quinic acid 11 according to literature $[66,67]$ was chlorinated with NCS with excellent face selectivity to give $\alpha$-chloroketone 58 via silylenolether in $45 \%$ yield in 2 steps. The following reduction of $\mathbf{5 8}$ with $\mathrm{NaBH}_{4}$ gave alcohol $\mathbf{5 7}$ as the sole product. The chemical yield of $\mathbf{5 7}$ was improved by sequential reactions from $45 \%$ in 2 steps to an overall yield of 57\% in 3 steps from ketone 59. Treatment of $\mathbf{5 7}$ with TFA in $\mathrm{MeOH}$ under reflux afforded tetraol $\mathbf{6 0}$ in $38 \%$ yield. Then, $\mathbf{6 0}$ was converted into acetonide 61, which was oxidized with Dess-Martin periodinane to give hydroxyketone 56. The isopropylidene moiety of 56 was removed with TFA because 56 could not be dehydrated by any dehydrating agents. One plausible explanation was that 56, conformationally fixed by an isopropylidene bridge, could not be transformed into a suitable transition state for dehydration. Resultant triol 62 was converted into reactive hydroxyketone 63 that was in turn dehydrated to enone 
64 with Martin's sulfrane dehydrating agent (bis[ $\alpha, \alpha$-bis(trifluoromethyl) benzyloxy] diphenyl sulfur) [68] in 65\% yield.<smiles>O=C(O)[C@]1(O)C[C@@H](O)[C@H](O)[C@H](O)C1</smiles>

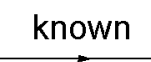

1) $\mathrm{TMSOTf} \mathrm{Et}_{3} \mathrm{~N}$

2) NCS, DMF<smiles>[Y]C1C(=O)[C@H]([OH2+])[C@@H]2C[C@]1(O)C(=O)O2</smiles>

59: $\mathrm{X}=\mathrm{H}$ 58: $\mathrm{X}=\mathrm{Cl}(45 \%$ in 2 steps $)$

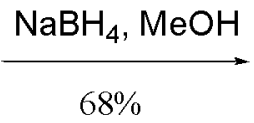

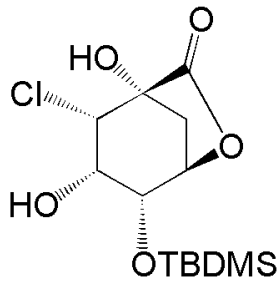

57

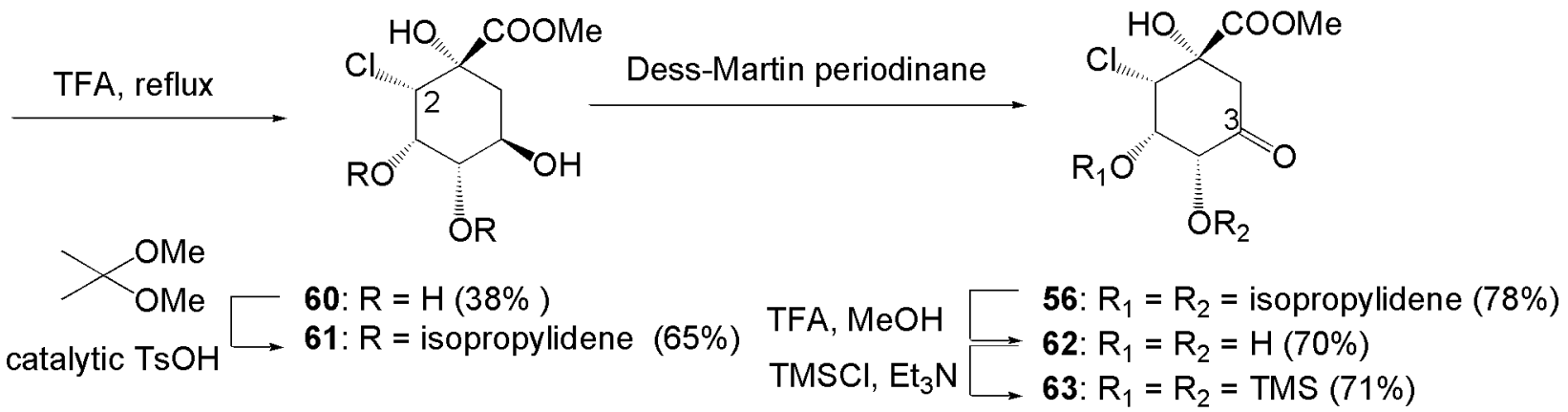

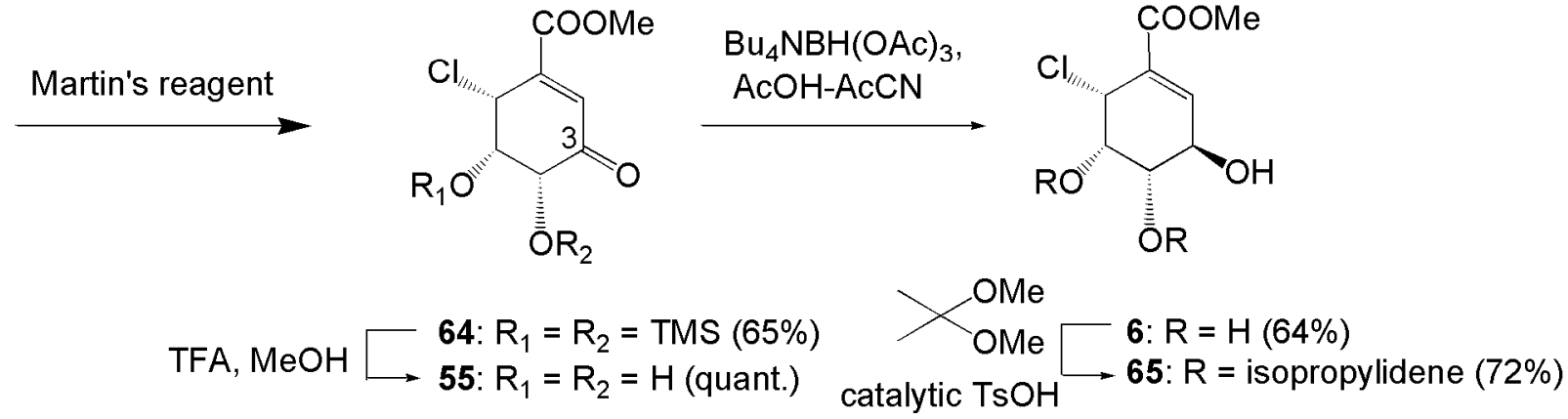

Scheme 7. Total synthesis of initially assigned pericosine A $\mathbf{6}$.

Treatment of enone 64 with TFA in $\mathrm{MeOH}$ gave 55, which was reduced stereoselectively with tetrabutylammonium triacetoxyborohydride [69] to afford 6 with the desired configuration as a single product. However, disagreement of the NMR data of 6 and acetonide 65 with those of natural pericosine A and those of its acetonide described in the literature [54] led us to conclude that the proposed stereochemistry of pericosine A was incorrect. Furthermore, the fact that "the isopropylidene bridge in 65 derived from 6 was located between C-4 and C-5, whereas that of the acetonide of pericosine A was between C-3 and C-4" [54] supported our conclusion.

Common intermediate 64 was reduced with $\mathrm{NaBH}_{4}$ to afford allyl alcohol 66 as a single product with opposite stereoselectivity. Then, $\mathbf{6 6}$ was deprotected to afford 9 quantitatively in 2 steps, as shown in Scheme 8. However, 9 was different from pericosine D. Then, product 9 was transformed into acetonide 67 to confirm the stereochemistry of the synthesized molecule. 
The stereochemistry of all intermediates in this study was carefully determined by analyzing various kinds of 2D NMR spectra.

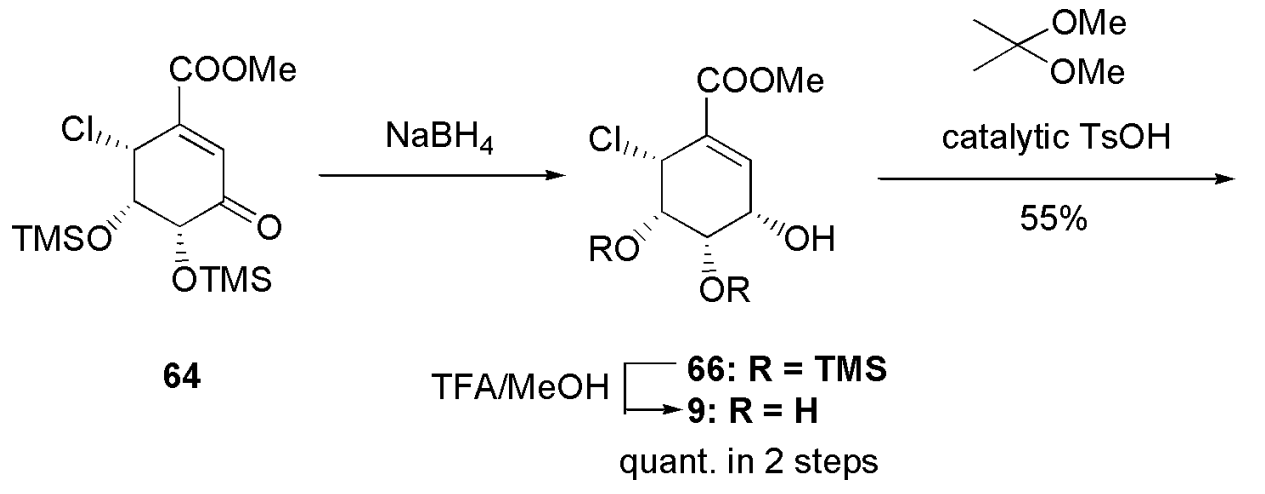

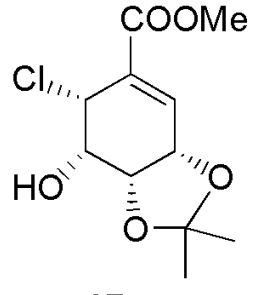

67

Scheme 8. Synthesis of initially assigned pericosine D 9.

\subsection{Total synthesis for structure revision and determination of absolute configuration of pericosine $A$} $[70,71]$

From our conclusion in the previous study described in Section 3.3, determination of the true structure of pericosine A by total synthesis became our next task. In a comprehensive review of data related to pericosines $[54,63,64]$, close similarity between the ${ }^{1} \mathrm{H}-\mathrm{NMR}$ coupling constants of natural pericosine A [54] and those of 7 [63] led us to deduce that the structure of natural pericosine A was $\mathbf{1}$, as illustrated in Figure 3.

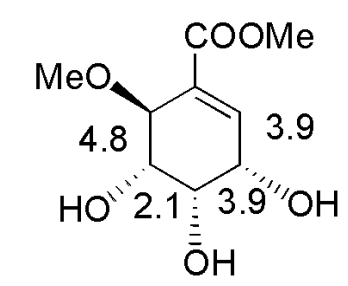

epimer of pericosine $B, 7$

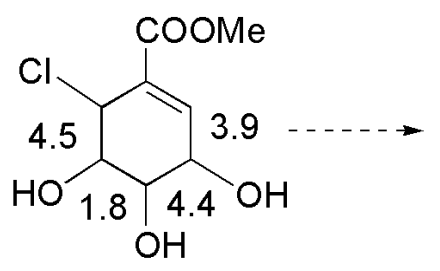

natural pericosine $\mathrm{A}$<smiles>COC(=O)C1=C[C@@H](O)[C@H](O)[C@H](O)[C@H]1Cl</smiles>

1

Coupling constants are expressed in $\mathrm{Hz}$.

Figure 3. Comparison of coupling constants between epimer of pericosine B 7 and pericosine A $\mathbf{1}$.

Since 1 had the same relative chemistry as 7 , our basic synthetic strategy was almost the same as that for 7. After a number of trials, the total synthesis of (-)-1 was achieved, as shown in Scheme 9. Known methyl 5-epishikimate derivative $\mathbf{6 8}$ derived from (-)-shikimic acid 9 was subjected to Dess-Martin oxidation to afford $\beta, \gamma$-unsaturated ketone 69. Without purification, 69 was reduced with $\mathrm{NaBH}_{4}$ to give alcohol (-)-70, which in turn was protected with TBSCl to give silyl ether 71. After dihydroxylation of 71, resultant diol 72 was acetylated to yield 73, and this was deprotected to give 74. Subsequent Dess-Martin oxidation of $\mathbf{7 4}$ gave $\beta$-hydroxyketone 75, which was dehydrated with TFAA to afford $\alpha, \beta$-unsaturated ketone 76. Subsequent reduction of 76 was carried out carefully with stoichiometric $\mathrm{NaBH}_{4}$ at $-78{ }^{\circ} \mathrm{C}$ in dry THF to afford alcohol 77 possessing the desired stereochemistry in $95 \%$ yield. 
<smiles>CC1CCCCC1C(=O)O</smiles>

$(-)$-shikimic acid 9<smiles>CC(=O)C1=C[C@@H]2OC3(CCCCC3)O[C@H]2[C@H](O)C1</smiles>

68

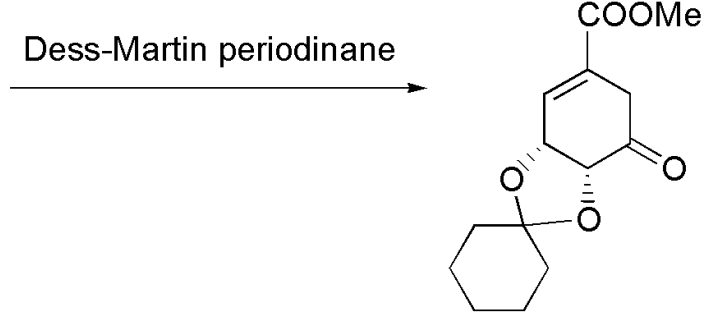

69
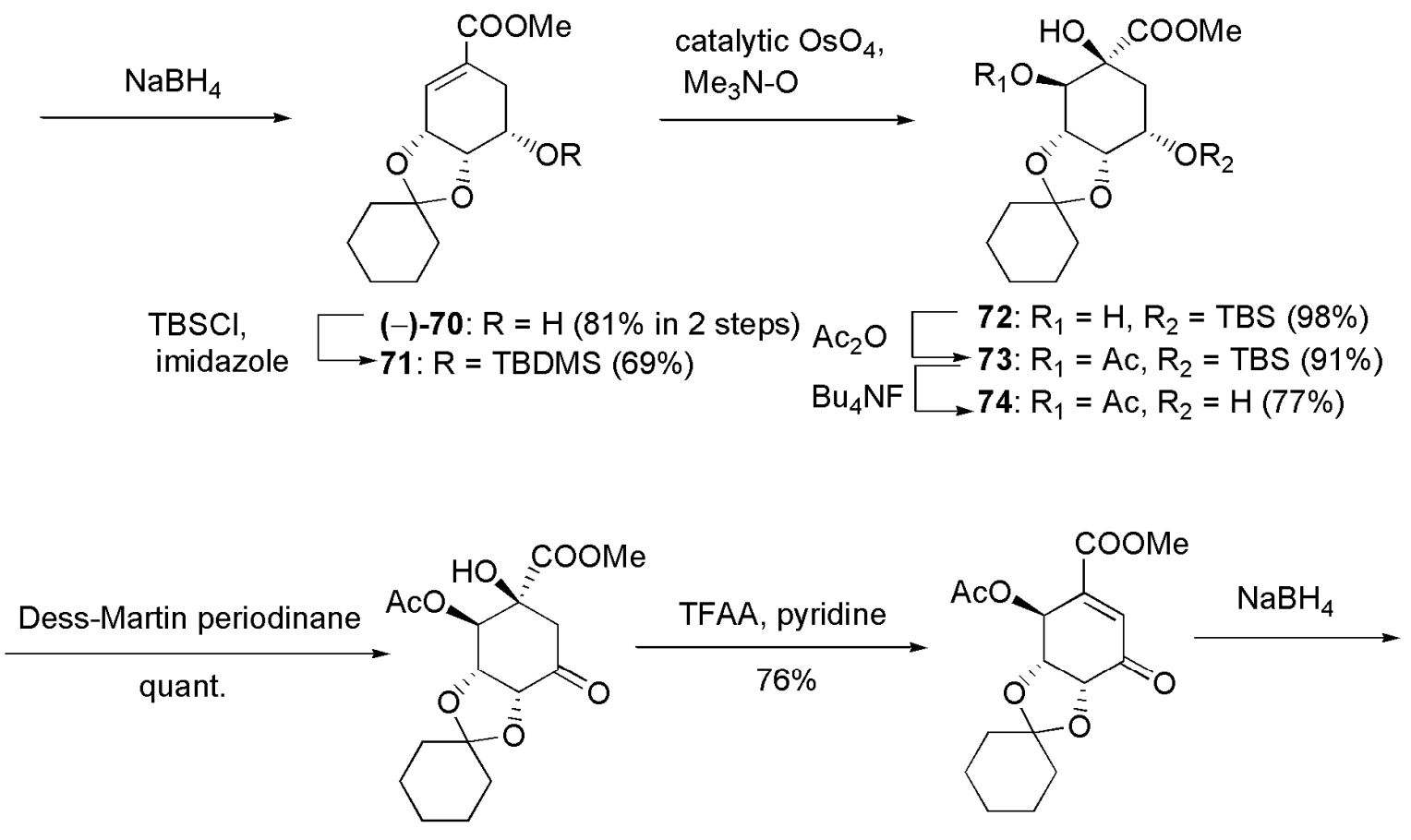

75

76

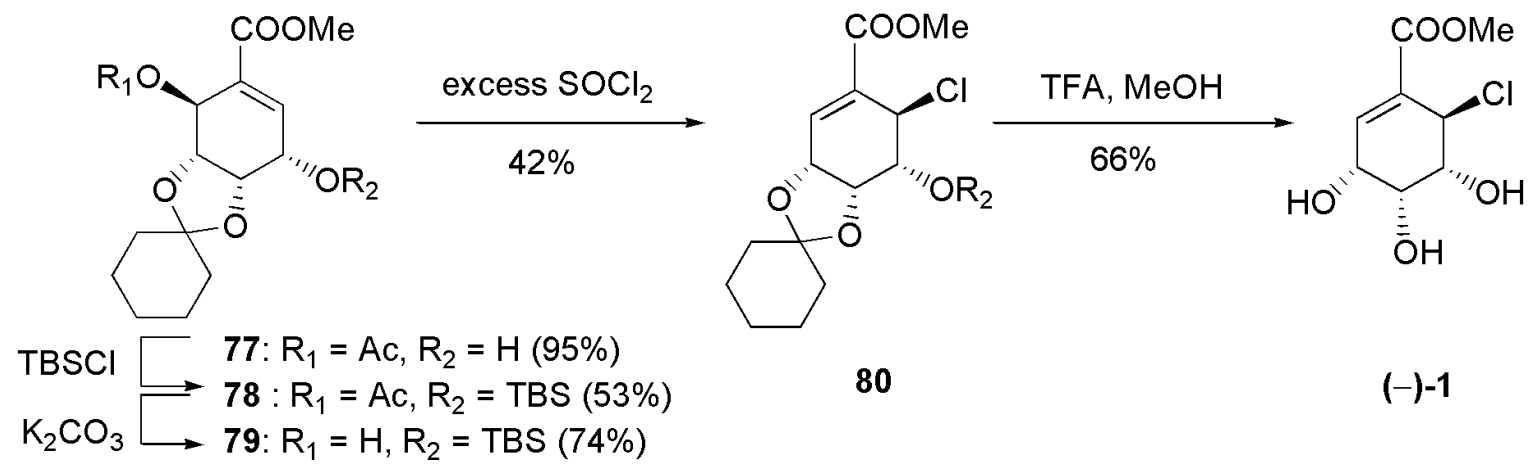

Scheme 9. First total synthesis of (-)-pericosine A 1 from (-)-shikimic acid.

Subsequent protection of $\mathbf{7 7}$ was carried out with careful addition of TBSCl and a stoichiometric amount of imidazole to give silyl ether $\mathbf{7 8}$ in $53 \%$ yield, followed by deacetylation with $\mathrm{K}_{2} \mathrm{CO}_{3}$ to afford enol 79 in $74 \%$ yield. The key reaction of this total synthesis, which was aimed at introducing a $\mathrm{Cl}$ atom, was achieved by the addition of excess $\mathrm{SOCl}_{2}$ to 79 in dry $\mathrm{CH}_{2} \mathrm{Cl}_{2}$ to afford chlorinated 
product 80 in $42 \%$ yield [71], whereas the yield of the reaction with stoichiometric $\mathrm{SOCl}_{2}$ was $10 \%$ [70]. To our surprise, $\mathbf{8 0}$ was formed with rearrangement of the double bond. The structure of key intermediate 80 was confirmed by detailed 1D and 2D NMR studies. In the NOESY spectra, cross peaks H-5/t-Bu, H-6/t-Bu, H-5/SiMe, H-6/SiMe, and H-3, H4/one of cyclohexyl methylenes, were observed. HMBC cross peak H-3, H-4/singlet carbon of 80, which was observed at $110.8 \mathrm{ppm}$, confirmed that the $\mathrm{Cl}$ atom was introduced not via an $\mathrm{S}_{\mathrm{N}} \mathrm{i}$ mechanism as we had aimed early on, but via an $\mathrm{S}_{\mathrm{N}} 2$ ' mechanism with syn selectivity. Another plausible mechanism is the [3,3]-sigmatropic rearrangement of chlorosulfonate derived from 79. In spite of detailed analysis of NMR spectra, the stereochemistry at C-6 in $\mathbf{8 0}$ could not be determined at this step. This total synthesis was completed with TFA to give final product (-)-1 in 66\% yield, which was not 9 as synthesized previously by us $[64,65]$ but pericosine A. Thus, this result proved the stereochemistry at C-6 in 80. Except for the sign of the specific rotation, (-)-1 showed the same spectroscopic data, including HPLC retention time, as the natural product, and the absolute configuration of natural pericosine A was assigned as methyl $(3 S, 4 S, 5 S, 6 S)$-6-chloro-3,4,5-trihydroxy-1-cyclohexene-1-carboxylate. The first total synthesis of the antipode of natural pericosine $\mathrm{A}$ was completed in this manner.

Next, the total synthesis of natural pericosine A (+)-1 was examined. As the preparation of $(+)-\mathbf{7 0}$, which is an antipode in the preceding synthesis, from 11 has been reported, a similar strategy toward ()-1 could be applicable. The synthesis of (+)-1 is summarized in Scheme 10 [71]. In our synthesis, the preparation of $(+)-\mathbf{7 0}$ was modified from the original method appearing in the literature. Treatment of hydroxylactone 78 derived from 11 with $\mathrm{NaOMe}$ in $\mathrm{MeOH}$ followed by neutralization with DOWEX ${ }^{\circledR}$ 50W-X8 gave crude diol 79, which was obtained by only filtration and used in the next reaction without further extraction or purification. Diol $\mathbf{7 9}$ was oxidized to $\beta$-hydroxyketone 80, which was then dehydrated with TFAA to produce enone 81. Reduction with $\mathrm{NaBH}_{4}$ afforded enol 82 in 54\% overall yield from 78. Enol 82 was converted into (+)-70 according to literature [72]. The following transformation of $(+)-\mathbf{7 0}$ into $(+)-\mathbf{1}$ was accomplished as above. Since all spectral data of synthesized (+)-1, including specific rotation and HPLC retention time, agreed with the data of natural pericosine $\mathrm{A}$, the first synthesis of natural pericosine $\mathrm{A}$ was completed.

\section{Further Discussion}

As described above, pericosines are interesting compounds because of their potent biological activities and unique structures. In particular, the role of pericosine A $\mathbf{1}$ in anti-tumor, protein kinase EGFR inhibition or topoisomerase II inhibition was demonstrated. In terms of chemical structure, the relative chemistry of pericosines A $\mathbf{1}, \mathrm{C} \mathbf{3}$, and B $\mathbf{2}$ is so unique that it is difficult to find the same configurational carbasugar natural products, whereas pericosine D $\mathbf{4}$ has the same relative configuration as (+)-MK7607. We are extremely interested in the fact that pericosines C 3 and E 5 exist as an enantiomeric mixture. How are they biologically formed? Pericosine E $\mathbf{5}$ is thought to be a conjugate of pericosines A 1 and B 2 but with different chiral sense. This suggests the possibility of the presence of antipodes of $\mathbf{1}$ and $\mathbf{2}$ or unknown analogues with other combinations. We are currently directing our efforts toward designing a more effective synthetic route for pericosine A $\mathbf{1}$ because of the low total yield in our completed first synthesis. Nevertheless, the SN2' type reaction, which is the 
key step for $\mathrm{Cl}$ introduction in our previous work [70,71], may help unravel the mystery surrounding the chirality of percosines. A reaction similar to this or the enantioselective dehydration from pro-chiral 3-epiquinate may occur in fungal metabolic systems to generate chirality. Indeed, it seems unbelievable that enantiomeric mixtures of $\mathbf{3}$ and $\mathbf{5}$, particularly $\mathbf{5}$ that bears 8 chiral centers, could be formed biologically. In that sense, pericosines are truly exciting compounds.
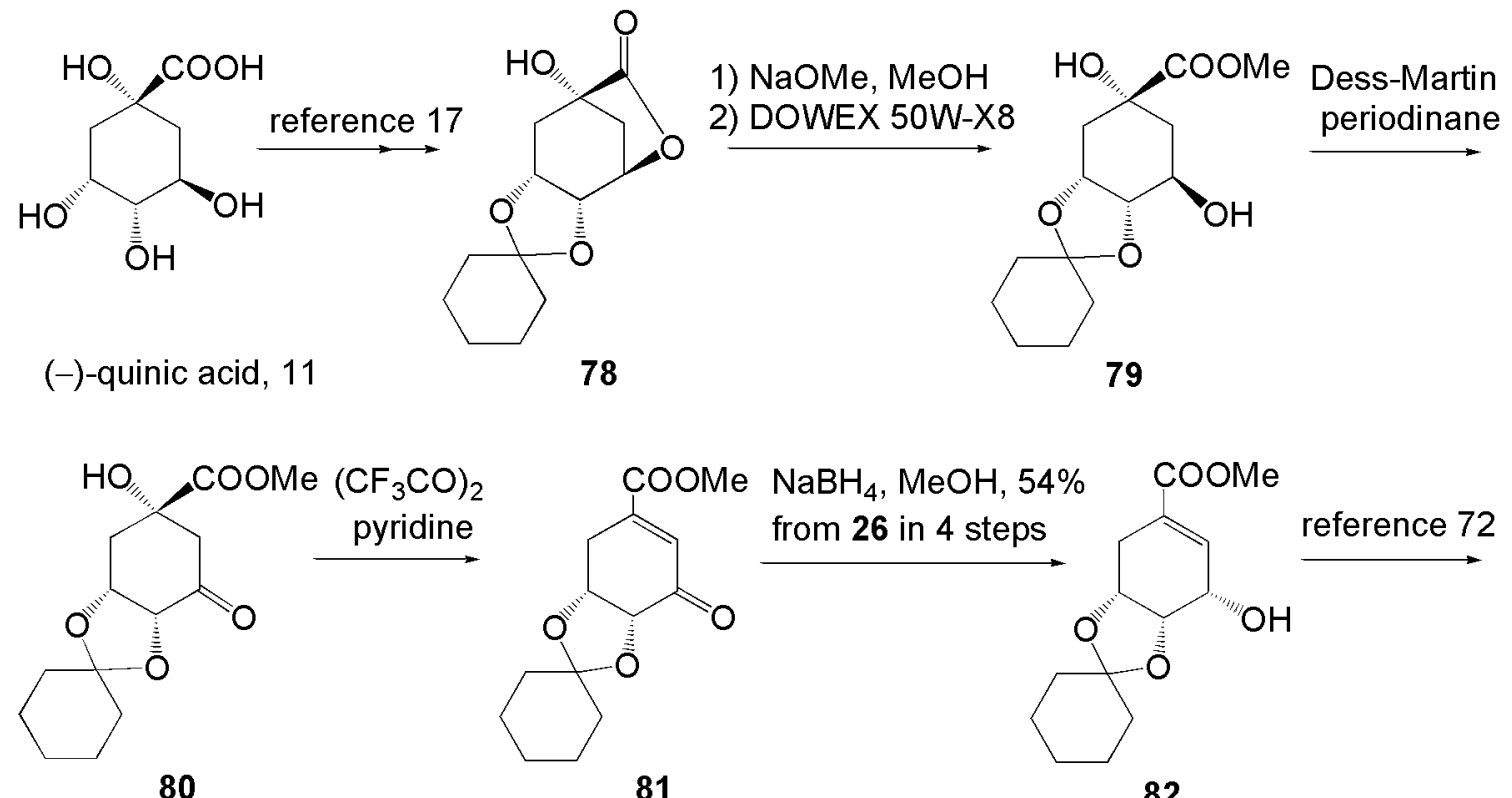<smiles>C=CC1OC2(CCCCC2)O[C@H]1C(O)CC(=CC)C(C)=O</smiles>

$(+)-70$<smiles>CC(=O)C1=C[C@@H](O)[C@H](O)[C@H](O)[C@H]1Cl</smiles>

$(+)-1$

Scheme 10. Total synthesis of (+)-pericosine A from (-)-quinic acid.

On the other hand, we would like to point out the ambiguity of the conformation of pericosines. It is absolutely difficult to determine the configuration or conformation of pericosines only from spectral analysis. ${ }^{1} \mathrm{H}-\mathrm{NMR}$ coupling constants of pericosines and acetonides are shown in Figure 4 . The correct structure of $\mathbf{1}$ could not be concluded only from the synthesis of $\mathbf{1}$. The stereochemistry of C-6 in intermediate $\mathbf{8 0}$ could be determined not from detailed spectral analysis but from the difference between deprotected 1 and 9, the latter of which was synthesized in our previous study [64, 65]. We hope to solve this problem by integrating our vast synthetic efforts with data from other researchers.

The synthetic study of pericosine D is ongoing in an effort to determine its absolute configuration [73]. After elucidating all the structures of pericosines, we will examine the biological activity of 
synthesized pericosine analogues, develop more effective synthetic routes, and design more active molecules based on these seed compounds.

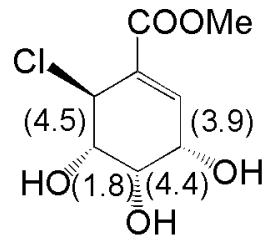

pericosine A 1

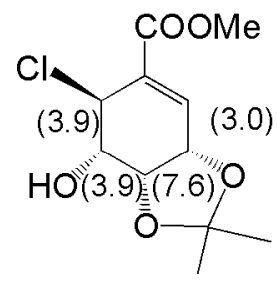

$1 a$

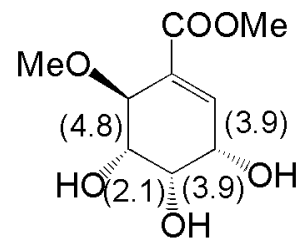

pericosine C 3

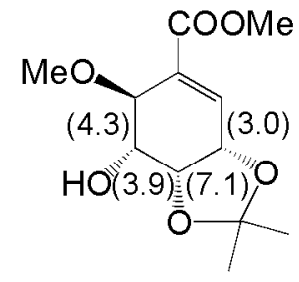

$3 \mathbf{a}$

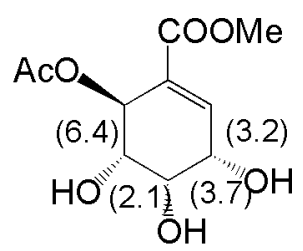

83

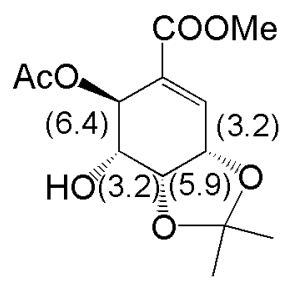

$83 a$

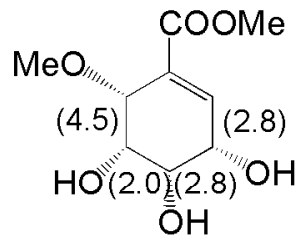

pericosine B 2

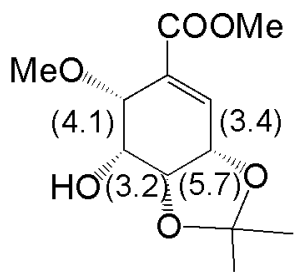

$2 a$

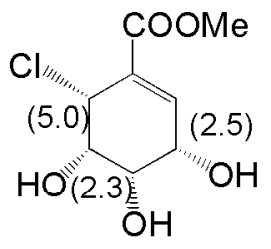

9

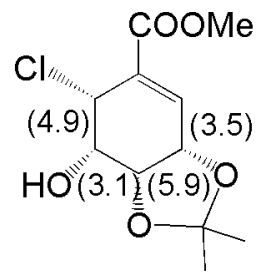

65 (9a)

Figure 4. Coupling constants in $\mathrm{Hz}$ observed in ${ }^{1} \mathrm{H}-\mathrm{NMR}$ spectra of pericosines and their analogues.

\section{Acknowledgements}

We are grateful to Dr. K. Minoura and Ms. M. Fujitake, and Dr. Takeshi Yamada of Osaka University of Pharmaceutical Sciences for NMR and MS measurements, and discussion concerning pericosines, respectively. This work was supported in part by a Grant-in-Aid for "High-Tech Research Center" Project for Private Universities: matching fund subsidy from MEXT (Ministry of Education, Culture, Sports, Science, and Technology), 2002-2006, Japan. 


\section{References and Notes}

1. Suami, T. Synthetic ventures in pseudo-sugar chemistry. Pure Appl. Chem. 1987, 59, 1509-1520; DOI 10.1351/pac198759111509.

2. Berecibar, A.; Grandjean, C.; Sinwardena, A. Synthesis and Biological Activity of Natural Aminocyclopentitol Glycosidase Inhibitors: Mannostatins, Trehazolin, Allosamidins, and Their Analogs. Chem. Rev. 1999, 99, 779-844; DOI 10.1021/cr9800331; PubMed 11749432.

3. Arjona, O.; Gomez, A. M.; Lopez, J. C.; Plumet, J. Synthesis and conformational and biological aspects of carbasugars. Chem. Rev. 2007, 107, 1919-2036; DOI 10.1021/cr0203701; PubMed 17488060.

4. Mirza, S.; Molleyres, L. P.; Vasella, A. Synthesis of a glyoxalase I inhibitor from Streptomyces griseosporeus Niida et Ogasawara. Helvetica Chimica Acta 1985, 68, 988-996; DOI 10.1002/hlca.19850680425.

5. Takayama, H.; Hayashi, K.; Koizumi, T. Enantioselective total synthesis of glyoxalase I inhibitor using asymmetric Diels-Alder reaction of a new chiral dienophile, (S)S-3-(3-trifluoromethylpyrid2-ylsulfinyl)acrylate. Tetrahedron Lett. 1986, 27, 5509-5512; DOI 10.1016/S0040-4039(00)852521.

6. Yamakoshi, Y.; Nakajima, Y.; Ge, W.-Y.; Sugita, J.; Okayama, K.; Takahashi, T.; Koizumi, T. High pressure mediated asymmetric Diels-Alder reaction of chiral sulfinylacrylate derivatives with furan and 2-methoxyfuran. Heterocycles 1996, 42, 129-133.

7. Takahashi, T.; Yamakoshi, Y.; Okayama, K.; Yamada, J.; Ge, W.-Y.; Koizumi, T. High-pressure mediated asymmetric Diels-Alder reaction of chiral sulfinylacrylate derivatives and its application to chiral synthesis of (-)-COTC and (-)-gabosine C. Heterocycles 2002, 56, 209-220.

8. Arthurs, C. L.; Wind, N. S.; Whitehead, R. C.; Stratford, I. J. Analogues of 2-crotonyloxymethyl(4R,5R,6R)-4,5,6-trihydroxycyclohex-2-enone (COTC) with anti-tumor properties. Bioorg. \& Med. Chem. Lett. 2007, 17, 553-557; DOI 10.1016/j.bmcl.2006.09.072.

9. Arthurs, C. L.; Raftery, J.; Whitby, H. L.; Whitehead, R. C.; Wind, N. S.; Stratford, I. J. Arene cisdihydrodiols: Useful precursors for the preparation of analogs of the antitumor agent, 2crotonyloxymethyl-(4R,5R,6R)-4,5,6-trihydroxycyclohex-2-enone (COTC). Bioorg. \& Med. Chem. Lett. 2007, 17, 5974-5977; DOI 10.1016/j.bmcl.2007.07.070.

10. Ramanaa, G.V.; Rao, B.V. Stereoselective synthesis of (-)-gabosine C using a Nozaki-HiyamaKishi reaction and RCM. Tetrahedron Lett. 2005, 46, 3049-3051; DOI: $10.1016 /$ j.tetlet.2005.03.018.

11. Huntley, C.F.M.; Wood, H.B.; Ganem, B. A new synthesis of the glyoxalase-I inhibitor COTC. Tetrahedron Lett. 2000, 41, 2031-2034; DOI 10.1016/S0040-4039(00)00103-9.

12. Huntley, C.F.; Hamilton, D.S.; Creighton, D.J.; Ganem, B. Reaction of COTC with glutathione: structure of the putative glyoxalase I inhibitor. Org. Lett. 2000, 2, 3143-3144; DOI 10.1021/ol006341z; PubMed 11009366.

13. Shing, T.; Tang, Y. Enantiospecific synthesis of 2-crotonyloxy-(4R,5R,6R)-4,5,6trihydroxycyclohex-2-enone (COTC) from quinic acid. J. Chem. Soc., Chem. Commun. 1990, 312. 
14. Shing, T.; Tang, Y. (-)-Quinic acid in organic synthesis. 1. A facile synthesis of 2crotonyloxymethyl-(4R,5R,6R)-4,5,6-trihydroxycyclohex-2-enone. Tetrahedron 1990, 46, 65756584.

15. Tatsuta, K.; Yasuda, S.; Araki, N.; Takahashi, M.; Kamiya, Y. Total synthesis of a glyoxalase I inhibitor and its precursor, (-)-KD16-U1. Tetrahedron Lett. 1998, 39, 401-402; DOI 10.1016/S0040-4039(97)10559-7.

16. Shinada, T.; Fuji, T.; Ohtani, Y.; Yoshida, Y.; Ohfune, Y. Syntheses of gabosine A, B, D, and E from allyl sulfide derived from (-)-quinic acid. Synlett. 2002, 1341-1343.

17. Lygo, B.; Swiatyj, M.; Trabsa, H.; Voyle, M. Synthesis of (+)-Gabosines C and E from D-ribose Tetrahedron Lett. 1994, 35, 4197-4200; DOI (Either ISSN and Title must be supplied).

18. Banwell, M. G.; Bray, A. M.; Wong, D. A concise and chemo-enzymatic synthesis of (-)-gabosine A, a carba-sugar enone from Streptomycetes. J. New J. Chem. 2001, 25, 1351-1354.

19. Lubineau, A.; Billault, I. New Access to Unsaturated Keto Carba Sugars (Gabosines) Using an Intramolecular Nozaki-Kishi Reaction as the Key Step. J. Org. Chem. 1998, 63, 5668-5671.

20. Alibes, R.; Bayon, P.; De March, P.; Figueredo, M.; Font, J.; Marjanet, G. Enantioselective synthesis and absolute configuration assignment of gabosine $\mathrm{O}$. Synthesis of $(+)$ - and (-)-gabosine $\mathrm{N}$ and (+)- and (-)-epigabosines N and O. Organic Lett. 2006, 8, 1617-1620.

21. Shing, T. K. M.; Cheng, H. M. Short Syntheses of Gabosine I and Gabosine G from $\delta$-DGluconolactone. J. Org. Chem. 2007, 72, 6610-6613; DOI 10.1021/jo0709697; PubMed 17637067.

22. Mehta, G.; Lakshminath, S. A norbornyl route to cyclohexitols: stereoselective synthesis of conduritol-E, allo-inositol, MK 7607 and gabosines. Tetrahedron Lett. 2000, 41, 3509-3512; DOI 10.1016/S0040-4039(00)00409-3.

23. Song, C.; Jiang, S.; Singh, G. Synthesis of (-)-MK7607 and Other Carbasugars from (-)-shikimic Acid. Synlett. 2001, 1983-1985.

24. Schmidt, R. R.; Koen, A. $\alpha$-Glucosidase inhibitors. Part 4. Synthesis of valienamine. Angew. Chem. 1987, 99, 490-491.

25. Park., T. K.; Danishefsky, S. J. A synthetic route to valienamine: an interesting observation concerning stereoelectronic preferences in the SN2' reaction. Tetrahedron Lett. 1994, 35, $2667-$ 2670; DOI 10.1016/S0040-4039(00)77001-8.

26. Fukase, H.; Horii, S. Synthesis of a branched-chain inosose derivative, a versatile synthon of Nsubstituted valiolamine derivatives from D-glucose. J. Org. Chem. 1992, 57, 3651-3658; DOI 10.1021/jo00039a026.

27. Trost, B. M.; Chupak, S.; Luebbers, T. Total Synthesis of $( \pm)$ - and (+)-Valienamine via a Strategy Derived from New Palladium-Catalyzed Reactions. J. Am. Chem. Soc. 1998, 120, 1732-1740; DOI 10.1021/ja973081g.

28. Shing, T. K. M.; Li, T. Y.; Kok, S. H.-L. Enantiospecific Syntheses of Valienamine and 2-epiValienamine. J. Org. Chem. 1999, 64, 1941-1946; DOI 10.1021/jo982024i; PubMed 11674286.

29. Yoshikawa, M.; Cha, B. C.; Okaichi, Y.; Takinami, Y.; Yokokawa, Y.; Kitagawa, I. Syntheses of validamine, epi-validamine, and valienamine, three optically active pseudo-amino-sugars, from Dglucose. Chem. Pharm. Bull. 1988, 36, 4236-4239.

30. Tatsuta, K.; Mukai, H.; Takahashi, M. Novel synthesis of natural pseudo-aminosugars, (+)valienamine and (+)-validamine. J. Antibiot. 2000, 53, 430-435; PubMed 10866227. 
31. Chang, Y.-K.; Lee, B.-Y.; Lee, G. S.; Jeon, H. B.; Kim, K. S. An Efficient Synthesis of Valienamine via Ring-Closing Metathesis. J. Org. Chem. 2005, 70, 3299-3302; PubMed 15823000.

32. von Itzstein, M.; Wu, W. Y.; Kok, G. B.; Pegg, M. S.; Dyason, J. C.; Jin, B.; Van, P. T.; Smythe, M. L.; White, H. F.; Oliver, S.W.; Colman, P. M.; Varghese, J. N.; Ryan, D. M.; Woods, J. M.; Bethell, R. C.; Hotham, V. J.; Cameron, J. M.; Penn, C. R Rational design of potent silalidasebased inhibitors of influenza virus replication. Nature 1993, 363, 418-423; PubMed 8502295.

33. Kim, C. U.; Lew, W.; Williams, M. A.; Zhang, L.; Liu, H.; Swaminathan, S.; Bischofberger, N.; Chen, M. S.; Tai, C. Y.; Mendel, D. B.; Laver, W. G.; Stevens, R. C. Influenza neuraminidase inhibitors possessing a novel hydrophobic interaction in the enzyme active site: design, synthesis, and structural analysis of carbocyclic sialic acid analogues with potent anti-influenza activity. $J$. Am. Chem. Soc. 1997, 119, 681-690; DOI 10.1021/ja963036t; PubMed 16526129.

34. Rohloff, J. C.; Kent, K. M.; Postich, M. J.; Becker, M. W.; Chapman, H. H.; Kelly, D. E.; Lew, W.; Louie, M. S.; McGee, L. R.; Prisbe, E. J.; Schultze, L. M.; Yu, R. H.; Zhang, L. Practical Total Synthesis of the Anti-Influenza Drug GS-4104. J. Org. Chem. 1998, 63, 4545-4550; DOI 10.1021/jo980330q.

35. Yeung, Y.-Y.; Hong, S.; Corey, E. J. A Short Enantioselective Pathway for the Synthesis of the Anti-Influenza Neuramidase Inhibitor Oseltamivir from 1,3-Butadiene and Acrylic Acid. J. Am. Chem. Soc. 2006, 128, 6310-6311; DOI 10.1021/ja0616433; PubMed 16683783.

36. Fukuta, Y.; Mita, T.; Fukuda, N.; Kanai, M.; Shibasaki. M., Catalytic Asymmetric Total Synthesis of (+)-Lactacystin. J. Am. Chem. Soc. 2006, 128, 6312-6313; PubMed 16683784.

37. Mita, T.; Fukuda, N.; Roca, F. X.; Kanai, M.; Shibasaki, M. Second generation catalytic asymmetric synthesis of Tamiflu: allylic substitution route. Org. Lett. 2007, 9, 259-262; DOI 10.1021/o1062663c; PubMed 17217279.

38. Satoh, N.; Akiba, T.; Yokoshima, S.; Fukuyama, T. A practical synthesis of (-)-oseltamivir. Angewandte Chem., Int. Ed. 2007, 46, 5734-5736; DOI 10.1002/anie.200701754.

39. Karchier, M.; Michalak, K.; Wicha, J. Anti-influenza drugs Synthesis of Tamiflu, a drug kept in stock to prevent a bird flu epidemic. Wiadomosci Chemiczne 2007, 61, 7-42.

40. Shie, J.-J.; Fang, J.-M.; Wang, S.-Y.; Tsai, K.-C.; Cheng, Y.-S. E.; Yang, A.-S.; Hsiao, S.-C.; Su, C.-Y.; Wong, C.-H. Synthesis of Tamiflu and its Phosphonate Congeners Possessing Potent AntiInfluenza Activity. J. Am. Chem. Soc. 2007, 129, 11892-11893; DOI 10.1021/ja073992i; PubMed 17850083.

41. Takeuchi, T.; Chimura, H.; Hamada, M.; Umezawa, H.; Yoshioka, O.; Oguchi, N.; Takahashi, Y.; Matsuda, A. Glyoxalase I inhibitor of a new structural type produced by Streptomyces. J. Antibiot. 1975, 28, 737-742; PubMed 1102510.

42. Tatsuta, K.; Tsuchiya, N.; Mikami, N.; Umezawa, S.; Umezawa, H.; Naganawa, H. KD16-U1, a new metabolite of Streptomyces. Isolation and structural studies. J. Antibiot 1974, 27, 579-586; PubMed 4436143.

43. Bach, G.; Breiding-Mack, S.; Grabley, S.; Hammann, P.; Hutter, K.; Thiericke, R.; Uhr, H.; Wink, J.; Zeeck, A. Secondary metabolites by chemical screening. 22. Gabosines, new carba-sugars from Streptomyces. Liebigs Ann. Chem. 1993, 241-250. 
44. Yoshikawa, N.; Chiba, N.; Mikawa, T.; Ueno, S.; Harimaya, K.; Iwata, M. Novel herbicidal MK7607 and its manufacture with Curvularia. Jpn. Kokai Tokkyo Koho JP 1994, 06306000.

45. Horii, S.; Iwasa, T.; Mizuta, E.; Kameda, Y. Validamycins, new antibiotics. VI. Validamine, hydroxyvalidamine, and validatol, new cyclitols. J. Antibiot. 1971, 24, 59-63; PubMed 5541335.

46. Kameda, Y.; Horii, S. Structure of the antibiotic validamycin A. J. Chem. Soc., Chem. Commun. 1972, 746-747.

47. Suami, T.; Ogawa, S.; Chida, N. The revised Structure of Validamycin A. J. Antibiot. 1980, 33, 9899; PubMed 7372560.

48. Laube, H.; Fouladfar, M.; Aubell, R.; Schmitz, H. Effect of glucosidase inhibitor, Bay g 5421 (acarbose), on the blood glucose in obese diabetic patients ty pe 2 (NIDDM). ArzneimittelForschung 1980, 30, 1154-1157; PubMed 7191299.

49. Moore, R. E.; Corbett, T. H.; Patterson, G. M. L.; Valeriote, F. A. The search for new antitumor drugs from blue-green algae. Current Pharmaceutical Design 1996, 2, 317-330.

50. Newman, D. J.; Cragg, G. M. Natural Products as Sources of New Drugs over the Last 25 Years. J. Nat. Prod. 2007, 70, 461-477; PubMed 17309302.

51. Fenical, W.; Jensen, P. R. Developing a new resource for drug discovery: marine actinomycete bactereia. Nature Chemical Biology 2006, 2, 666-673; DOI 10.1038/nchembio841; PubMed 17108984.

52. Newman, D. J.; Cragg, G. M. Natural products from marine invertebrates and microbes as modulators of antitumor targets. Current Drug Targets 2006, 7, 279-304; DOI 10.2174/138945006776054960; PubMed 16515528.

53. Newman, D. J.; Hill, R. T. New drugs from marine microbes: the tide is turning. J. Ind. Microbiol. Biotechnol. 2006, 33, 539-544; DOI 10.1007/s10295-006-0115-2; PubMed 16598493.

54. Numata, A.; Iritani, M.; Yamada, T.; Minoura, K.; Matsumura, E.; Yamori, T.; Tsuruo, T. Novel antitumor metabolites produced by a fungal strain from a sea hare. Tetrahedron Lett. 1997, 38, 8215-8218; DOI 10.1016/S0040-4039(97)10198-8.

55. Yamada, T.; Iritani, M.; Ohishi, H.; Tanaka, K.; Doi, M.; Minoura, K.; Numata, A. Pericosines , antitumor metabolites from the sea hare-derived fungus Periconia byssoides. Structures and biological activities. Org. Bioorg. Chem. 2007, 5, 3979-3986.

56. Yamada, T.; Minoura, K.; Numata, A. In Proc. of the 119th Annual Meeting of the Pharmaceutical Society of Japan, Tokushima, Japan, 1999; Abstract 2, p. 159.

57. Yamada, T. Ph. D. Thesis, Osaka University of Pharmaceutical Sciences, Japan, 2002.

58. Donohoe, T. J.; Blades, K.; Helliwell, M.; Waring, M. J.; Newcombe, N. J. The Total Synthesis of (+)-Pericosine B. Tetrahedron Lett. 1998, 39, 8755-8758; DOI 10.1016/S0040-4039(98)01989-3.

59. Okamura, H.; Nakamura, Y.; Morishige, K.; Ohura, R.; Shimizu, H.; Iwakawa, T.; Nakatani, M. Development of Base Catalized Diels-Alder Reaction of 3-Hydroxy-2-pyrone and its Application to Synthesis of Biologically Active Compounds. 40th Tennen Yuki Kagobutsu Toronkai Koen Yoshisyu, Fukuoka, Japan, 1988; pp.187-192.

60. Usami, Y.; Numata, A. Examination of the reactivities of hydroxy groups in multioxygenated cyclohexanoids: Synthetic study toward cytotoxic pericosine B. Chem. Pharm. Bull. 2004, 52, 1125-1129; DOI 10.1248/cpb.52.1125; PubMed 15340203. 
61. Garcia Ruano, J.; Alemparte, C.; Lopez-Cantarero, J. (Z)-3-p-Tolylsulfinylacrylonitrile as a Chiral Dienophile: Diels-Alder Reactions with Furan and Acyclic Dienes. J. Org. Chem. 2000, 65, 79387943; DOI 10.1021/jo000963g; PubMed 11073601.

62. Garcia Ruano, J.; Lopez-Cantarero, J.; Martin Castro, A. M.; Adams, H.; Rogriguez Ramos, J. H. toward the Synthesis of (+)-Pericosine B. Phosphorus, Sulfur and Silicon and the Related Elements 2005, 180, 1493-1494; DOI 10.1080/10426500590913339.

63. Usami, Y.; Hatsuno, C.; Yamamoto, H.; Tanabe, M.; Numata, A. Synthesis of the epimer of pericosine B from (-)-quinic acid. Chem. Pharm. Bull. 2004, 52, 1130-1133; PubMed 15340204.

64. Usami, Y.; Ueda, Y. Synthetic Study toward Antitumour Natural Product Pericosine A. Chem. Lett. 2005, 34, 1062-1063; DOI 10.1246/c1.2005.1062.

65. Usami, Y.; Ueda, Y. Stereoselective Syntheses of Diastereomers of Antitumor Natural Product Pericosine A from (-)-Quinic Anid. Synthesis 2007, 3219-3225.

66. Manthey, M. K.; Gonzalez-Bello, C.; Abell, C. Synthesis of (2R)-2bromodehydroquinic acid and (2R)-2fluorodehydroquinic acid. J. Chem. Soc., Perkin Trans 1997, 625-628.

67. Gonzalez-Bello, C.; Manthey, M. K.; Harris, J. H.; Hawkins, A. R.; Coggins, J.R.; Abell, C. Synthesis of 2-Bromo- and 2-Fluoro-3-dehydroshikimic Acids and 2-Bromo- and 2-Fluoroshikimic Acids Using Synthetic and Enzymic Approaches. J. Org. Chem. 1998, 63, 1591-1597.

68. Alhalt, R. J.; Martin, J. C. Sulfuranes. VI. Reactions involving the alkoxy ligands of dialkoxydiarylsulfuranes. Formation of olefins and ethers. J. Am. Chem. Soc. 1972, 94, 5003-5010.

69. Evans, D. A.; Chapman, K. T. The directed reduction of $\beta$-hydroxy ketones employing $\mathrm{Me}_{4} \mathrm{NHB}(\mathrm{OAc})_{3}$. Tetrahedron Lett. 1986, 27, 5939-5942; DOI 10.1016/S0040-4039(00)85367-8.

70. Usami, Y.; Horibe, Y.; Takaoka, I.; Ichikawa, H.; Arimoto, M. First Total Synthesis of (-)Pericosine A from (-)-Shikimic Acid: Structure Revision and Determination of the Absolute Configuration of Antitumor Natural Product Pericosine A. Synlett 2006, 1598-1600.

71. Usami, Y.; Takaoka, I.; Ichikawa, H.; Horibe, Y.; Tomiyama, S.; Ohtsuka, M.; Imanishi, Y.; Arimoto, M. First Total Synthesis of (+)- and (-)-Pericosine A: Determination of Absolute Stereo Structure. J. Org. Chem. 2007, 72, 6127-6134; PubMed 17628106.

72. Ulibarri, G.; Nadler, W.; Skrydstrup, T.; Audrain, H.; Chianori, A.; Riche, C.; Grierson, A. A. Construction of the Bicyclic Core Structure of the Enediyne Antibiotic Esperamicin- $\mathrm{A}_{1}$ in Either Enantiomeric Form from (-)-Quinic Acid. J. Org. Chem. 1995, 60, 2753-2761.

73. Usami, Y.; Mizuki, K.; Ichikawa, H.; Arimoto, M. In Proc. of the 57th Annual Meeting of the Pharmaceutical Society of Japan Kinki-branch, Osaka, Japan, 2007; p. 36.

(C) 2008 by MDPI (http://www.mdpi.org). Reproduction is permitted for noncommercial purposes. 